УДК 615.218.2,615.035.1

Л. В. ЯКОВЛСВА, д-р фарм. наук, проф., О. Г. БЕРДНИК, А. О. ГУРТЯКОВА

Національний фармацевтичний університет, м. Харків

АНАЛІЗ АСОРТИМЕНТУ, ДОСТУПНОСТІ Й ОБСЯГІВ СПОЖИВАННЯ АНТИГІСТАМІННИХ ЛІКАРСЬКИХ ЗАСОБІВ В УКРАЇНІ

Ключові слова: антигістамінні лікарські засоби, асортимент, доступність, обсяги споживання

L.V. IAKOVLIEVA, O. G. BERDNIK, A. O. GURTYAKOVA

National University of Pharmacy, Kharkiv

\title{
ANALYSIS OF ASSORTMENT AND VOLUMES OF CONSUMPTION OF ANTIHISTAMIN PREPARATIONS IN UKRAINE
}

Key words: antihistamines, assortment, pharmacoeconomic availability, consumption volume

Алергійні захворювання займають лідируючі позиції в структурі хвороб людини за соціально-економічним збитком, впливом на рівень здоров'я та якість життя пацієнтів. Як показали дослідження, за останні 30 років поширеність алергійних захворювань кожні 10 років подвоюється. Згідно з даними ВООЗ, в даний час близько 5\% дорослого населення планети та $15 \%$ дитячого страждають на алергійні захворювання. Одним із найпоширеніших алергійних захворювань $є$ алергічний риніт, за даними різних авторів його поширеність серед населення досягає $10-35 \%[1,2]$.

В основі алергійних захворювань лежить IgE-опосередкована реакція запалення, що має загальну патогенетичну природу, а отже, і загальні принципи терапії. Численні медіатори запалення (гістамін, цитокіни, інтерлейкіни, хемокіни) сприяють розвитку хронічного алергійного запалення і підтримують його клінічні прояви. При цьому основним медіатором алергійного запалення залишається гістамін, 3 яким пов'язані такі біохімічні ефекти, як підвищення накопичення цГМФ, посилення хемотаксису нейтрофілів та еозинофілів, збільшення синтезу простагландинів, гальмування міграції еозинофілів. У свою чергу, це призводить до розвитку клінічних ефектів: скорочення гладкої мускулатури бронхів і кишечнику, спазму судин малого кола кровообігу, підвищення секреції слизових залоз носа та решти дихальних шляхів, посилення секреції парієтальними клітинами шлунка соляної кислоти. Таким чином, клінічні прояви алергійної реакції безпосередньо зумовлені дією гістаміну на Н1-гстамінові рецептори [3]. Для лікування алергійних захворювань використовують антигістамінні лікарські засоби (Л3) - Н1-гістаміноблокатори, дія яких опосередкована їх взаємодією з рецепторами гістаміну на клітинах різних тканин і органів. Ці засоби залежно від часу створення прийнято поділяти на три покоління.

До групи антигістамінних ЛЗ І покоління належать: дифенгідрамін (димедрол), хлорфенірамін (супрастин), прометазин (піпольфен), клемастин (тавегіл), ципрогептадин (перитол), мебгідролін (діазолін), диметиндену малеат (феністил), хіфенадин (фенкарол), яким притаманний седативний ефект, а деякі ЛЗ цієї групи (наприклад доксиламін) використовують як снодійні засоби. Лікарські засоби I покоління (хлорфенірамін, дифенгідрамін, прометазин) мають виражену антихолінергічну дію, внаслідок чого виникають психомоторні розлади. Усі ЛЗ I покоління потенціюють дію седативних і снодійних ЛЗ, наркотичних і ненаркотичних аналгетиків, інгібіторів МАО, а також алкоголю. За рахунок безлічі точок прикладення антигістамінні ЛЗ І покоління спричинюють виражену сухість слизових оболонок порожнини рота, носоглотки, бронхів, розлади сечовипускання, погіршення зору [3].

(C) Колектив авторів, 2018 
Антигістамінні ЛЗ І покоління мають досить короткий період напіввиведення, що збільшує кратність їх прийому до 3-4 разів на добу. Також одним із їх недоліків є зниження терапевтичної активності при прийомі більш ніж 7-10 днів, що обмежує їх застосування у разі лікування хронічної алергійної реакції, а також використання 3 профілактичною метою. Однак антигістамінні ЛЗ I покоління $\epsilon$ препаратами вибору у разі лікування гострих алергійних станів, оскільки за парентерального введення починають діяти значно швидше, ніж пероральні засоби інших поколінь [3].

Антигістамінні засоби II покоління (астемізол, лоратадин, ебастин, акривастин, цетиризин) мають високу специфічність і спорідненість до Н1- гістамінових рецепторів за відсутності впливу на серотонінові й М-холінорецептори, швидкий початок клінічного ефекту (через 30-60 хв) і тривалий період дії (24-48 год). Вони клінічно ефективніші, не сприяють збільшенню маси тіла, мають менш виражений седативний ефект, а отже, не впливають на когнітивні функції у хворих, насамперед це стосується лоратадину. Антигістамінні ЛЗ ІІ покоління значно рідше спричинюють небажані побічні дії з боку ЦНС [4]. Недоліком деяких із цих засобів (терфенадину і астемізолу) є можливість розвитку важких серцевих шлуночкових аритмій через подовження інтервалу QT, особливо у разі комбінації з макролідами і деякими протигрибковими засобами через потребу додаткового метаболізму в печінці системою цитохрому Р450. Значною перевагою цієї групи ЛЗ порівняно з ЛЗ І покоління є відсутність тахіфілаксії, що дає змогу продовжити їх прийом на період до одного місяця [3].

До антигістамінних засобів III покоління належать фексофенадин (Телфаст) i дезлоратадин (Еріус), які дуже швидко блокують Н1-гістамінові рецептори. Для них характерна відсутність кардіотоксичної дії, седативних і психомоторних реакцій, тахіфілаксії, біотрансформація лише незначної частини прийнятого ЛЗ, а в остаточному підсумку - виразна клінічна ефективність. Обидва ЛЗ приймають незалежно від прийому їжі, їх ефект розвивається вже протягом перших 24 год [3, 4].

Незважаючи на те, що алергійні захворювання давно відомі в медицині, у сучасному світі проблеми, пов’язані з питаннями діагностики, профілактики й особливо якісної терапії алергопатологій, залишаються досить актуальними.

Мета дослідження - аналіз асортименту антигістамінних ЛЗ на фармацевтичному ринку України, визначення доступності для споживачів за показником Ca.s. та їх обсягів споживання за ATC/DDD-методологією протягом 2014-2017 pp.

У статті проаналізовано асортимент антигістамінних ЛЗ на фармацевтичному ринку України, розраховані обсяги їх споживання і показники адекватності платоспроможності (Ca.s.) населення України відносно цієї групи препаратів за чотири роки (2014-2017pp.), що дає змогу оцінити їх доступність для населення та відслідковувати динаміку досліджуваних показників.

\section{М а т е рі ал и та ме тоди дослідження}

Представлені на фармацевтичному ринку України антигістамінні лікарські засоби аналізували за даними аналітичної системи дослідження фармацевтичного ринку «Фармстандарт» компанії «МОРОН» [5]. Як показник соціально-економічної доступності антигістамінних ЛЗ був розрахований показник адекватності платоспроможності (Ca.s.) за формулою:

$$
\text { Ca.s. }=\mathrm{P} / \text { Wa.w. } \cdot 100 \% \text {, }
$$

де Ca.s. $€$ показником платоспроможності населення, що фактично характеризує доступність Л3;

P - середньозважена ціна однієї упаковки ЛЗ у рік;

Wa.w. - середня заробітна плата за рік. 
У цій роботі показник доступності Ca.s. представлений як частка середньої заробітної плати у відсотках, необхідна для придбання однісї упаковки антигістамінного Л3 [6]. Значення величини середньої заробітної плати в Україні за досліджувані роки знаходили на сайті: www.ukrstat.gov.ua [7].

За визначеними показниками доступності антигістамінних ЛЗ останні були розподілені на високодоступні, середньодоступні, малодоступні. Високодоступні Л3 - Ca.s. < 5\%; средньодоступні - 5\% < Ca.s. $<15 \%$; малодоступні - Ca.s. $>15 \%$.

Об'єми споживання антигістамінних ЛЗ досліджували за допомогою рекомендованої BOO3 ATC/DDD-методології, яка застосовує класифікаційну систему ATC (Anatomic Therapeutic Chemical Classification System) та одиницю виміру DDD (Defined Daily Dose), яка $\epsilon$ визначеною добовою дозою в грамах [2, 8]. Метод застосовують для моніторингу споживання ЛЗ, які становлять особливий інтерес для суспільства 3 точки зору серйозних медико-соціальних та економічних наслідків їх нераціонального застосування. Для розрахунку обсягів споживання антигістамінних Л3 використано показник DDDs на 1000 жителів на день (DDDs/1 000 жителів/день). Відомості про величини DDD отримані на сайті BOO3: www.who.int/countries/ukr. DDDs - це кількість визначених середніх добових доз (DDD), які спожиті хворими на певній території (у конкретному регіоні, закладі охорони здоров'я) за певний період (місяць, квартал, рік). У цьому дослідженні розрахунки здійснювали за кожний рік протягом 4-х років.

\section{Результати дослідження та обговорення}

Антигістамінні ЛЗ системного застосування (за міжнародною АТС-класифікацією належать до групи R 06) представлені на фармацевтичному ринку України в широкому асортименті - 17 МНН, на основі яких за досліджуваний період (2014-2017рр.) представлено 150-172 ТН. У 2014 р. було нараховано 172 ТН, із яких 83 ТН вітчизняного виробництва та 89 ТН іноземного виробництва. У 2015 р. - 159 ТН, із яких 78 ТН вітчизняного виробництва та 81 ТН іноземного виробництва. У 2016 р. - 150 TH, із яких 75 ТН вітчизняного виробництва та 75 ТН іноземного виробництва. В 2017 р. -160 TH, із яких 78 ТН вітчизняного виробництва та 82 ТН іноземного виробництва.

Серед представлених антигістамінних ЛЗ майже в однаковому співвідношенні препарати як вітчизняного, так і іноземного виробництва. Близько 47\% наявних ТН виробляють в Україні. Серед найпоширеніших зарубіжних виробників на ринку України представлені ЛЗ виробництва: Індії (21 ТН), Швейцарії (17 TH), Великої Британії (11 TH), Угорщини (10 TH), Польщі (8 TH), Ізраїля (7 TH), Турції (6 TH), Латвії (4 TH), Бельгії (3 TH), Німеччини та США (по 2 TH), Канади (1 TH) та ін.

Перші рейтингові позиції за кількістю ТН займають такі групи МНН: лоратадин (протягом 4 років кількість ТН знизилася з 35 до 29); дезлоратадин (протягом 4 років кількість ТН зросла від 26 до 30); левоцетиризин (збільшилася кількість ТН від 24 до 29 ТН) (табл. 1).

Спостерігається збільшення на українському фармацевтичному ринку кількості TH із групи III покоління антигістамінних засобів (протягом 4 років кількість ТН зросла від 44 до 69 ТН). Це свідчить про тенденції осучаснення антигістамінного лікування з уникненням більшості побічних ефектів ЛЗ I та II поколінь, споживання яких поступово зменшилося за 4 роки (із 49 до 43 TH I покоління та 357 до 47 TH II покоління відповідно) (табл. 1).

Аналіз асортименту ЛЗ антигістамінної дії за формою випуску свідчить, що питома вага таблеток у 2017 р. є найбільшою та становить 51,55\%, сиропів - 17,53\%, розчини для ін'єкцій і порошки (по 7,22\%) займають третю позицію. 


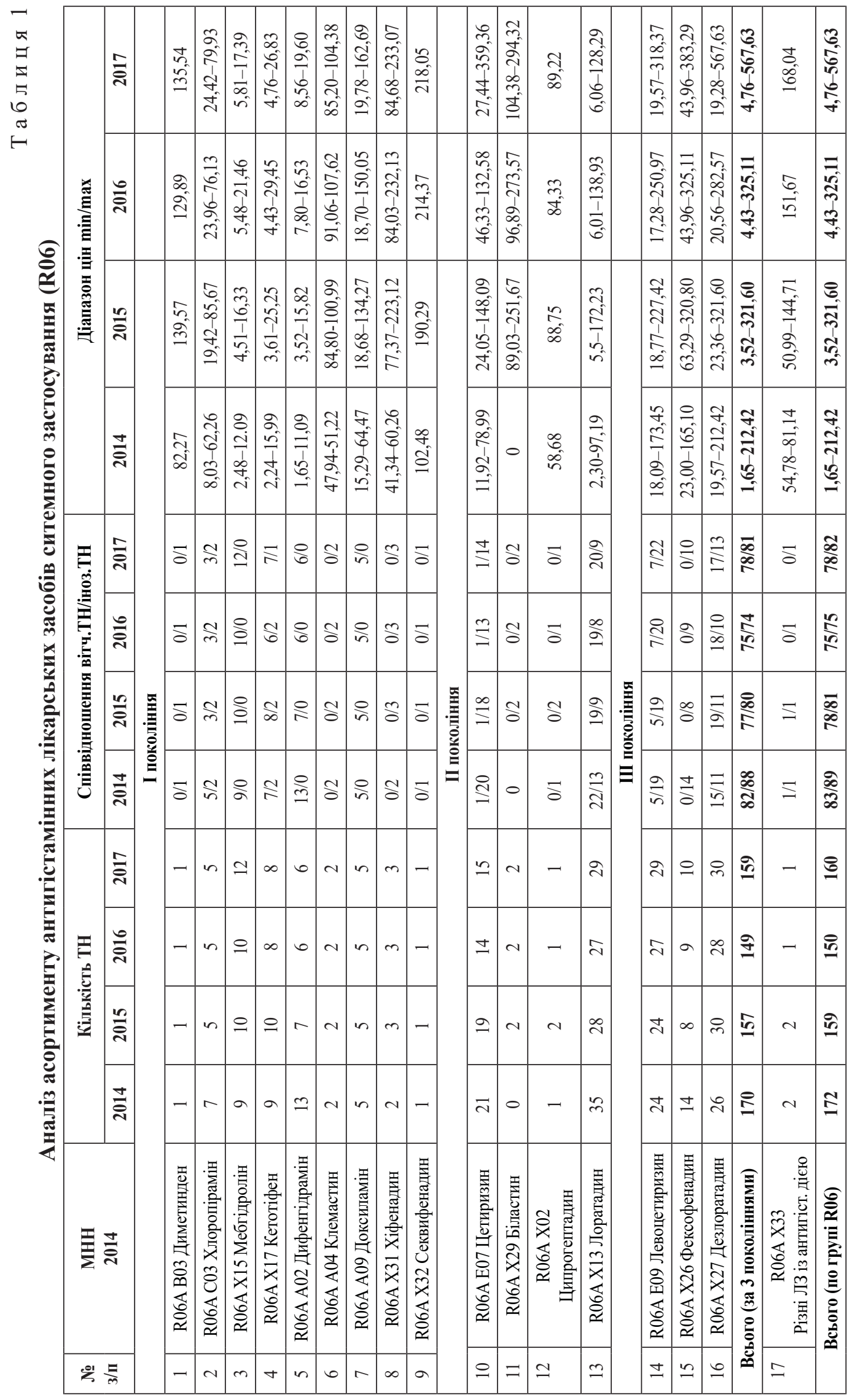


Залежно від виробника ціни варіювали від низьких до високих, а саме діапазон цін від 1,65 грн. (Димедрол, Луганський ХФЗ ВАТ, Луганськ, Україна, табл. 50 мг, блістер, № 10) до 212,43 грн. (Еpiyc $®$, Bayer Consumer Health, Швейцарія, табл. в/плівк. обол. 5 мг, блістер, № 30) у 2014 р. та від 4,76 грн. (Кетотифен, Лекхім ПАТ Київ, Україна, табл. 0,001 г, блістер, в пачці, № 10) до 567,63 грн (Ерiус®, Bayer Consumer Health, Швейцария, табл. в/плів. обол. 5 мг, блістер, № 30) у 2017 р., що давало можливість індивідуального вибору ЛЗ із урахуванням діючих компонентів, лікарської форми і ціни протягом всього періоду дослідження.

Оскільки витрати на лікування більшості алергійних захворювань в нашій країні пацієнт оплачує з власних коштів, цінова доступність якісного ЛЗ має велике значення. За розрахованими значеннями показника Ca.s встановлено, що антигістамінні ЛЗ для населення України протягом усіх чотирьох років представлені переважно високодоступними ТН. Тільки незначна частина ЛЗ є середньодоступними: $14,29 \%$ iз препаратів фексофенадина та $3,22 \%$ із препаратів дезлоратадина. Низький показник адекватності платоспроможності (Ca.s.) до 5\% підтверджує доступність ЛЗ групи R06 і гарантує їх споживання в умовах низької платоспроможності населення.

На останньому етапі досліджували обсяги споживання антигістамінних ЛЗ, результати наведено в табл. 2.

Т а б ли ц я 2

Обсяги споживання антигістамінних лікарських засобів (DDDs/1000 жителів/день)

\begin{tabular}{|c|c|c|c|c|}
\hline \multirow{2}{*}{ АТС код/МНН } & \multicolumn{4}{|c|}{ Роки } \\
\hline & 2014 & 2015 & 2016 & 2017 \\
\hline R06А В03 Діметинден & 0,09 & 0,08 & 0,06 & 0,09 \\
\hline R06А C03 Хлоропірамін & 0,22 & 0,19 & 0,23 & 0,15 \\
\hline R06A X15 Мебгідролін & 1,38 & 1,28 & 1,25 & 1,23 \\
\hline R06A X17 Кетотифен & 0,32 & 0,32 & 0,34 & 0,35 \\
\hline R06A A02 Дифенгідрамін & 0,05 & 0,024 & 0,017 & 0,022 \\
\hline R06А А04 Клемастин & 0,15 & 0,11 & 0,10 & 0,12 \\
\hline R06A A09 Доксиламін & 0,027 & 0,025 & 0,025 & 0,029 \\
\hline R06A X31 Хіфенадин & 0,0016 & 0,0012 & 0,0013 & 0,0015 \\
\hline \multirow[t]{2}{*}{ R06A X32 Секвіфенадин } & 0,0007 & 0,0005 & 0,0006 & 0,0009 \\
\hline & 2,24 & 2,03 & 2,03 & $1,99 \downarrow$ \\
\hline R06A E07 Цетиризин & 1,78 & 1,34 & 1,69 & 1,94 \\
\hline R06A X29 Біластин & - & 0,0005 & 0,045 & 0,08 \\
\hline R06A X02 Ципрогептадин & 0,0015 & 0,0013 & 0,0002 & 0,0002 \\
\hline \multirow[t]{2}{*}{ R06A X13 Лоратадин } & 2,62 & 2,75 & 3,03 & 2,62 \\
\hline & 4,41 & 4,09 & 4,77 & $4,64 \uparrow$ \\
\hline R06А Е09 Левоцетиризин & 1,91 & 1,95 & 2,21 & 2,53 \\
\hline R06A X26 Фексофенадин & 0,098 & 0,08 & 0,13 & 0,17 \\
\hline \multirow[t]{2}{*}{ R06А X27 Дезлоратадин } & 0,98 & 0,72 & 1,09 & 1,27 \\
\hline & 2,99 & 2,75 & 3,43 & $3,97 \uparrow$ \\
\hline Всього & 9,64 & 8,87 & 10,23 & $10,60 \uparrow$ \\
\hline
\end{tabular}


Отримані результати свідчать, що використання антигістамінних ЛЗ збільшилося протягом досліджуваного періоду (від 9,64 DDDs/1 000 жителів/день у 2014 р. до 10,60 DDDs/1 000 жителів/день у 2017 р.). Аналіз отриманих даних демонструє, що найбільша питома вага в загальній структурі споживання антигістамінних лікарських засобів I покоління характерна для препаратів на основі МНН мебгідролін (пік споживання в 2014 р. - 1,38 DDDs/1 000 жителів/день). Найімовірніше, це зумовлено тим, що препарат представлений на ринку лише вітчизняними виробниками, що значно знижує його вартість. Він наявний у вигляді 5 лікарських форм, серед яких є дитячі дозування, що сприяє безпечному застосуванню у педіатричній практиці. Крім того, мебгідролін, який належить до антигістамінних препаратів I покоління, застосовують у медичній практиці досить тривалий час, що надає йому певні переваги (наприклад прогнозованість побічних ефектів тощо). Але споживання ЛЗ мебгідроліна протягом 3 років знизилось майже на $10 \%$.

Найбільша питома вага в загальній структурі споживання антигістамінних лікарських засобів II покоління характерна для ЛЗ із діючою речовиною лоратадин (пік споживання в 2016 р. - 3,03 DDDs/1 000 жителів/день). Це зумовлено низкою причин: широкий асортимент торгових найменувань (27 TH), декілька видів лікарських форм, достатньо висока ефективність і відносно невисока вартість. Досить активно також споживався в цій групі Цетиризин, обсяг споживання якого збільшився за досліджуваний період від 1,78 до 1,94 DDDs/1 000 жителів/день.

Обсяг споживання антигістамінних препаратів III покоління на основі МНН дезлоратадин збільшився з 0,98 до 1,27 DDDs/1 000 жителів/день 32014 по 2017 рр. відповідно, тобто майже на $23 \%$. Об'єми споживання левоцетиризину також були значними і зросли з 2014 по 2017 pp. із 1,91 до 2,53 DDDs/1 000 жителів/день.

Таким чином, найспоживанішими протягом досліджуваних чотирьох років були ЛЗ п’яти МНН: мебгідролін, цетиризин, лоратадин, левоцетиризин і дезлоратадин, що належать до усіх трьох поколінь антигістамінних засобів. Споживання цієї групи найбільш вживаних ЛЗ становило упродовж досліджуваного періоду 89,94\%, 90,64\%, 90,70\% і 90,47\% відповідно по рокам.

Виходячи 3 показників загальних об'ємів споживання антигістамінних ЛЗ та враховуючи, що кількість хворих на алергійні захворювання становить близько 20\% населення України, встановлено, що у 2014 р. 0,96\% населення країни отримувало антигістамінні ЛЗ кожний день протягом року, що за перерахунком відповідає лише 5,86\% хворих, які 2 рази на рік курсом 1 місяць споживали антигістамінні Л3; у 2015 р. 0,89\% населення отримувало антигістамінні ЛЗ кожний день протягом року, що відповідає лише 5,39\% хворих; у 2016 р. 0,92\% населення отримувало антигістамінні ЛЗ кожний день протягом року, що відповідає лише 5,62\% хворих; у 2017 р. 1,11\% населення отримувало антигістамінні Л3 кожний день протягом року, що відповідає лише 6,87\% хворих. Як було зазначено у вступі, 20\% населення хворіс на алергійні захворювання. Тобто існує велика кількість хворих, які не отримують якісної адекватної антигістамінної терапії.

\section{В и с н о в к и}

1. Упродовж 2014-2017 рр. спостерігається зменшення кількості ТН антигістамінних ЛЗ на тлі збільшення кількості МНН - від 172 ТН на основі 16 МНН у 2014 p. до $160 \mathrm{TH}$ на основі 17 МНН у 2017 р. Кількісне співвідношення вітчизняних та зарубіжних виробників істотно не змінилось. Асортимент антигістамінних ЛЗ на 2017 p. досить широкий. На фармацевтичному ринку України представлені ЛЗ всіх трьох поколінь. Залежно від виробника, ціни варіювали від низьких до високих, а саме діапазон цін був від 1,65 грн. до 212,43 грн. у 2014 р. та від 4,76 грн. до 567,63 грн. 
у 2017 р., що давало можливість індивідуального вибору ЛЗ із урахуванням діючих компонентів, лікарської форми і ціни.

2. За отриманими результатами показників Ca.s встановлено, що антигістамінні ЛЗ для населення України протягом усіх чотирьох років представлені переважно високодоступними ТН. Тільки 14,29\% із препаратів фексофенадина (у 2014 р.) та 3,22\% із препаратів дезлоратадина (у 2015 р.) є середньодоступними. Низький показник адекватності платоспроможності (Ca.s.) до 5\% підтверджує доступність Л3 групи R06 і гарантує їх споживання в умовах зниження економічного розвитку в Україні.

3. За результатами аналізу об'ємів споживання антигістамінних ЛЗ у DDDs/1 000 жителів/день відзначено зростання споживання цих препаратів із кожним роком від 9,64 у 2014 р. до 10,60 у 2017 р. При цьому збільшився обсяг споживання препаратів останнього покоління - МНН дезлоратадина (від 0,98 у 2014 р. до 1,27 у 2017 р.) та МНН левоцетиризина (від 1,91 у 2014 р. до 2,53 у 2017 р.), які мають вигідні фармакокінетичні особливості та оптимальне співвідношення ефективність/ безпека. Стабільно великим залишається обсяг споживання препаратів II покоління: лоратадина (2,62 як у 2014 так і у 2017 рр.), цетиризина (від 1,78 у 2014 р. до 1,94 у 2017 р.). Поряд із досить високою фармакологічною активністю вони мають відносно невисоку вартість, тому що в основному представлені на фармацевтичному ринку у вигляді генеричних версій.

4. На тлі тенденції росту споживання антигістамінних ЛЗ в Україні протягом чотирьох останніх років (від 9,64 DDDs/1 000 жителів/день у 2014 р. до 10,60 DDDs/1 000 жителів/день у 2017 р.) встановлено, що в Україні існує велика кількість хворих (близько 13\%), які отримують не в повному обсязі, або взагалі не отримують якісної адекватної антигістамінної терапії.

\section{С пи сок використаної літе ратури}

1. Недельская С. Н., Бессикало Т. Г. Аллергия и антигистаминные препараты // Новости медицины и фармации. - 2007. - № 8 (212). - С. 3.

2. http://www.who.int/countries/ukr

3. Катилов О. В., Синчук М. І., Дмитрієв Д. В., Мазулов О. В. Антигістамінні препарати в педіатричній практиці // Медицина світу [Електронний ресурс]. Режим доступу: http://msvitu.com/archive/2007/november/article-6.php?print=1

4. Зупанец И. А., Черных В. П., Попов С. Б. и др. Фармацевтическая опека // Лечение симптомов аллергии. - 2003. - С. 299-319.

5. Система дослідження ринку лікарських засобів «Фармстандарт» компанії «Моріон» [Електронний ресурс]. - Режим доступу: http://www.pharmstandart.com.ua (Дата звернення: 10.12.2017 р.)

6. Фармакоекономіка: навчальний посібник для студентів вузів / За ред. Л. В. Яковлєвої. - Вінниця: Нова Книга, 2009. - С. 175-176.

7. www.ukrstat.gov.ua

8. Морозов А. М., Яковлєва Л. В., Степаненко А. В. та ін. Вивчення споживання лікарських засобів за анатомо-терапевтично-хімічною класифікацією та встановленими добовими дозами (ATC/DDD-методологія): Метод. Рекомендації. - К.: НФаУ, ДЕЦ МОЗ України, 2013. - 32 с.

Надійшла до редакції 6 березня 2018 року. 
Л. В. Яковлева, О. Г. Бердник, А. А. Гуртякова

Национальный фармачевтический университет, г. Харьков

АНАЛИЗ АССОРТИМЕНТА, ДОСТУПНОСТИ И ОБЪЕМОВ ПОТРЕБЛЕНИЯ

АНТИГИСТАМИННЫХ ЛЕКАРСТВЕННЫХ СРЕДСТВ В УКРАИНЕ

Ключевые слова: антигистаминные лекарственные средства, ассортимент, доступность, объемы потребления

А Н Н О Т А ЦИ Я

За последние 30 лет распространенность аллергических заболеваний каждые 10 лет удваивается. Согласно данным ВОЗ, в настоящее время около 5\% взрослого населения планеты и 15\% детского страдают аллергическими заболеваниями.

Цель исследования - анализ ассортимента антигистаминных лекарственных средств на фармацевтическом рынке Украины, определение доступности для потребителей по показателю Ca.s. и объемов их потребления по ATC/DDD-методологии в течение 2014-2017 годов.

Представленные на фармацевтическом рынке Украины антигистаминные лекарственные средства анализировали по данным аналитической системы исследования фармацевтического рынка «Фармстандарт» компании «МОРИОН». В качестве показателя социально-экономической доступности антигистаминных лекарственных средств был рассчитан показатель адекватности платежеспособности Ca.s. Объемы потребления антигистаминных лекарственных средств исследовали с помощью рекомендованной BO3 ATC/DDD-методологии. Сведения о величинах DDD получены на сайте ВОЗ.

В течение исследуемого периода наблюдалось уменьшение количества торгових названий на фоне увеличения количества международных непатентованных наименований всех трех поколений. Количественное соотношение отечественных и зарубежных производителей существенно не изменилось.

По полученным результатам показателей Ca.s. установлено, что антигистаминные лекарственные средства для населения Украины в течение всех четырех лет представлены преимущественно высокодоступными лекарственными средствами. Только 14,29\% из препаратов фексофенадина (в 2014 г.) и 3,22\% из препаратов дезлоратадина (в 2015 г.) являются среднедоступными. Низкий показатель адекватности платежеспособности (Ca.s.) до 5\% подтверждает доступность лекарственных средств группы R06 и гарантирует их потребление в условиях снижения экономического развития в Украине.

Наиболее употребляемыми в течение исследуемых четырех лет были лекарственные средства пяти международных непатентованных наименований: мебгидролин, цетиризин, лоратадин, левоцетиризин и дезлоратадин, относящиеся ко всем трем поколениям антигистаминных лекарственных средств. Потребление этой группы лекарственных средств составляло в течение исследуемого периода 89,94\%, $90,64 \%, 90,70 \%$ и 90,47\% соответственно по годам от общего объема потребления антигистаминных лекарственных средств.

В течение 2014-2017 годов наблюдается уменьшение количества торговых названий антигистаминных лекарственных средств на фоне увеличения количества международных непатентованных наименований: от 172 торговых названий на основе 16 международных непатентованных наименований в 2014 году до 160 торговых названий на основе 17 международных непатентованных наименований в 2017 году. Количественное соотношение отечественных и зарубежных производителей существенно не изменилось. Ассортимент антигистаминных лекарственных средств по состоянию на 2017 год достаточно широк. На фармацевтическом рынке Украины представлены лекарственные средства всех трех поколений. В зависимости от про- 
изводителя, цены варьировали от низких до высоких, а именно диапазон цен от 1,65 грн. до 212,43 грн. в 2014 году и от 4,76 грн. до 567,63 грн. в 2017 году, что давало возможность индивидуального выбора лекарственных средств с учетом действующих компонентов, лекарственной формы и цены.

По результатам анализа объемов потребления антигистаминных лекарственных средств в DDDs/1 000 жителей/день, отмечен рост потребления этих препаратов с каждым годом от 9,64 в 2014 году до 10,60 в 2017 году. При этом увеличился объем потребления препаратов последнего поколения: международных непатентованных наименований дезлоратадина (от 0,98 в 2014 году до 1,27 в 2017 году) и левоцетиризина (от 1,91 в 2014 году до 2,53 в 2017 году), которые имеют выгодные фармакокинетические особенности и оптимальное соотношение эффективность/безопасность. Стабильно большим остается объем потребления препаратов II поколения: лоратадин (2,62 как в 2014, так и в 2017 году), цетиризин (от 1,78 в 2014 году до 1,94 в 2017 году). Наряду с достаточно высокой фармакологической активностью они имеют относительно невысокую стоимость, так как в основном представлены на фармацевтическом рынке в виде генерических версий.

На фоне тенденции роста потребления антигистаминных лекарственных средств в Украине в течение четырех последних лет (от 9,64 DDDs/1 000 жителей/день в 2014 году до 10,60 DDDs/1 000 жителей/день в 2017 году) установлено, что в Украине существует большое количество больных, которые получают не в полном объеме, либо вообще не получают качественную адекватную антигистаминную терапию.

L. V. Iakovlieva, O. G. Berdnik, A. O. Gurtyakova

National University of Pharmacy, Kharkiv

ANALYSIS OF ASSORTMENT AND VOLUMES OF CONSUMPTION OF ANTIHISTAMIN PREPARATIONS IN UKRAINE

Key words: antihistamines, assortment, pharmacoeconomic availability, consumption volume

A B S T R A C T

Over the past 30 years, the prevalence of allergic diseases has doubled every 10 years. According to WHO, currently about $5 \%$ of the world's adult population and $15 \%$ of children suffer from allergic diseases.

The purpose of the study is to analyze the assortment of antihistamines in the pharmaceutical market of Ukraine, determine the availability for consumers by the indicator of Ca.s. and their volumes of consumption by ATS/DDD-methodology during 2014-2017.

Represented in the pharmaceutical market of Ukraine antihistamines were analyzed according to the analytical system of research of the pharmaceutical market «Pharmstandard» of the company «MORION». As an indicator of socio-economic accessibility of antihistamines, an indicator of the adequacy of the solvency of Ca.s. Volumes of consumption of antihistamines were examined using the WHO recommended ATC/DDD methodology. Information on the DDD values is available on the WHO website: www.who.int/countries/ukr.

During the period under study, there was a decrease in the number of TNs against the background of an increase in the number of INNs of all three generations. The quantitative ratio of domestic and foreign producers has not changed significantly.

Based on the results of the Ca.s. found that antihistamines for the population of Ukraine for all four years are mainly high-availability drugs. And only $14.29 \%$ of fexofenadine preparations (in 2014) and 3.22\% of desloratadine preparations (in 2015) are mediumaccessible. The low indicator of the adequacy of solvency (Ca.s.) to $5 \%$, confirms the 
availability of drugs group R06 and guarantees their consumption in the face of a decline in economic development in Ukraine.

The most consumed during the studied four years were LS of five INNs: Mebrogroline, Cetirizine, Loratadine, Levocetirizine and Desloratadine, related to all three generations of antihistamines. Consumption of this group of the most used drugs during the study period was $89.94 \%, 90.64 \%, 90.70 \%$ and $90.47 \%$, respectively, over the years of total consumption of antihistamines.

During 2014-2017 there is a decrease in the number of TN drugs against the background of an increase in the number of INN: from $172 \mathrm{TN}$ on the basis of 16 INN in 2014 to $160 \mathrm{TN}$ on the basis of 17 INNs in 2017. The quantitative ratio of domestic and foreign producers has not changed significantly. The assortment of antihistamine drugs for 2017 is quite wide. On the pharmaceutical market of Ukraine are represented drugs of all three generations. Depending on the manufacturer, the prices varied from low to high, namely the spread of prices from 1.65 UAH to $212.43 \mathrm{UAH}$ in 2014 and from $4.76 \mathrm{UAH}$ to $567.63 \mathrm{UAH}$ in 2017, which made it possible to select individual drugs taking into account the active ingredients, dosage form and price.

According to the results of the Ca.s indices, it is established that antihistamines for the population of Ukraine for the entire four years are represented mainly by high-availability TN. And only $14.29 \%$ of fexofenadine preparations (in 2014) and 3.22\% of desloratadine preparations (in 2015) are medium-accessible. The low indicator of the adequacy of solvency (Ca.s.) to 5\%, confirms the availability of drugs group R06 and guarantees their consumption in the face of a decline in economic development in Ukraine.

According to the analysis of the consumption of antihistamines in DDDs/1000 inhabitants/day, the increase in the consumption of these drugs was observed every year from 9.64 in 2014 to 10.60 in 2017. At the same time, the consumption of the latest generation drugs increased: INN desloratadine (from 0.98 in 2014 to 1.27 in 2017) and INN levocetirizine (from 1.91 in 2014 to 2.53 in 2017), which have profitable pharmacokinetic characteristics and the optimal efficiency / safety ratio. The consumption of secondgeneration drugs remains stably large: loratadine (2.62 in both 2014 and 2017), cetirizine (from 1.78 in 2014 to 1.94 in 2017). Along with sufficiently high pharmacological activity, they have a relatively low cost, since they are mainly presented in the pharmaceutical market in the form of generic versions.

Against the background of the trend of increasing consumption of antihistamines in Ukraine over the last four years (from 9.64 DDDs/1000 inhabitants/day in 2014 to 10.60 DDDs/1000 inhabitants/day in 2017), it is established that in Ukraine there is a large number patients who do not receive in full, or do not receive quality adequate antihistamine therapy at all.

Електронна адреса для листування завторами:feknfau@ukr.net 